\title{
Some geometrical aspects of fusiform planispiral shape in larger foraminifera
}

\author{
MARTIN D. BRASIER \\ Department of Geology, University of Hull, Cottingham Road, Hull HU6 7RX, England
}

\begin{abstract}
Fusiform planispiral tests are found in many lineages of larger foraminifera (e.g. fusulinids, lituolids, alveolinids, soritids, amphisteginids) in which a general trend from spherical or discoidal to elongate test shape has often been noted. Geometrical models are used to illustrate an increasing surface area and the shortened spiral lines of communication of such a trend, with whorl and chamber proportions and volume or spiral length held constant. The suggestion that fusiform planispiral growth is a device to shorten lines of communication from the proloculus to the poles is questioned.
\end{abstract}

\section{INTRODUCTION}

Fusiform planispiral growth is one of several kinds of architecture frequently found in larger foraminifera. Both structural studies (e.g. Hottinger, 1978) and geometrical modelling (Brasier, 1982a) show that the shapes and growth plans utilised by these larger foraminifera have relatively short internal to external lines of communication for a given biomass, measured from the proloculus to the nearest aperture in contact with the external milieu. This reduced minimum line of communication ('MinLOC') is also enhanced by the construction of chambers with a compressed shape, or arranged in cycles, and by the presence of numerous apertures. Furthermore, the distance from the most remote corner of a chamber to the nearest foramen or aperture ('MaxLOC') is also relatively short in the larger foraminifera and invariably much less than the longest diameter of the chamber. This condition can therefore be contrasted with the longer lines of communication (for a unit volume) in the tests of non-septate and primitive septate taxa such as those in the Tournayellidae or Miliolidae (Brasier, 1982b).

The trend from small to large size and from longer to shorter lines of communication has recurred frequently in the foraminifera and is a good example of $\mathrm{K}$-selection, in which predictable conditions favour large individual size as a consequence of low reproduction rates and delayed maturation (e.g. Tappan, 1976; Hottinger, 1982). A cyclic pattern is evident in this trend, with culmination in the late Palaeozoic and again in the late Cretaceous to Recent (Brasier, 1982b), a pattern compared by Hottinger with the episodes of global cooling.

Although lines of communication seem to be important in the architecture of larger foraminifera, there are also significant external constraints on test form, such as a sessile or mobile life habit, the need for strength and the requirements of any endosymbionts. The discoidal forms are noted for their relatively sessile life habit (e.g.
Amphisorus) or for an epibenthic habit (e.g. Heterostegina) but even more, perhaps, for the presence of endosymbiotic algae which means they need adequate illumination for photosynthesis. Such foraminifera must therefore harmonise the needs of a high surface area to volume ratio (for the better reception of sunlight and for better adhesion) with the need for shorter lines of communication (for mobility of nutrients, vacuoles and organelles). Annular or cyclic chambers are both good solutions to this problem.

In areas of relatively mobile carbonate sand, such delicate discoidal tests will not survive and the prevailing test type is biconvex or fusiform, involute, and therefore more robust (Brasier, 1975a). Peneroplis proteus, Archaias angulatus (soritids) and Borelis pulchrus (an alveolinid) are typical inhabitants of the mobile sand facies in the Caribbean (Brasier, 1975b). The soritids are relatively small individuals of species which, in the adult form, attain large size and are found attached to seagrasses or algae (e.g. Brasier, 1975b, 1975c) and it is possible that the early involute stage favours dispersal between patches of vegetation. Borelis is a small, nearly spherical alveolinid which, together with the elongate Alveolinella, is the only surviving example of the formerly important fusiform planispiral type of larger foraminifera. Neither of these has a shape well adapted to living on vegetation such as seagrass. Fossil alveolinids and fusulinids often occur with calcareous algae in conditions that were probably clear and shallow with strong currents (e.g. Bignot \& Guernet, 1976; Ross, 1969) and a life style as free-wheeling rollers may be envisaged for this growth form (Haynes, 1981, p. 53).

Although a wide range of foraminiferid architecture has been modelled in an earlier paper (Brasier, 1982a), the fusiform planispiral shape was not included. The aim of this paper is therefore to examine some simple geometrical models of this important growth form with respect to surface area and to the minimum lines of com- 
munication within the test. It is instructive to begin by reviewing the basic evolutionary trends shared by these fusiform foraminifera.

\section{EVOLUTION OF FUSIFORM PLANISPIRAL TESTS}

We are not concerned here with those evolutionary trends that led to fusiform growth since these are reviewed elsewhere (Brasier, 1982a and in preparation). It should be noted, however, that modelling of these antecedent trends indicates that shortening of the lines of communication (for a unit volume) was taking place. This is seen in the trend from elongate to short chambers, as for example in the change from Tournayellidae or Chernyshinellidae to Endothyridae, and from Miliolidae to Alveolinidae. Another important trend has involved the transformation of evolute chambers into involute ones, as exemplified in the gradual evolution of the Endothyridae and Ozawainellidae (e.g. Thompson, 1964), in the abrupt and iterative change from Miliolidae to Alveolinidae (e.g. Smout, 1963) and perhaps in the lineage from early species of Ammobaculites (e.g. A. pyriformis) through to later Lituolidae.

A third trend, modelled in Fig. 1, is the change from a small, rounded (or even discoidal) ancestor to a larger elongate fusiform descendent. In fusulinids this is illustrated by the development from the discoidal ozawainellids (e.g. Millerella), through nearly spherical Stafellidae (e.g. Rauserella, Sphaerulina) to the fusiform Fusulinidae (e.g. Fusulina). A similar trend is found in the Schubertellinae, from the ellipsoidal Eoschubertella to very elongate Paraboultonia, and also in the Neoschwagerininae (Thompson, 1964). An analagous series of changes is found in the Cretaceous alveolinids, from small globular species of Ovalveolina and Praealveolina to larger, more fusiform species of Praealveolina and Subalveolina (Smout, 1963). Glomalveolina is a small globular form of Paleocene to Eocene age that almost certainly arose independently from a miliolid ancestor, and from this were derived a range of elongate to cylindrical species of Alveolina (Hottinger, 1960, 1963). The pattern was again repeated in the Upper Eocene when the small globular Borelis first appeared, with subsequent evolution into globular to fusiform Flosculinella and into very elongate Alveolinella (Smout, 1963). Parallel trends that are less well known include the evolution of elongate Loftusia from a globular Paracyclammina-like ancestor in the Late Cretaceous, the evolution of the fusiform rotaliid Boreloides from a discoidal amphisteginid in the Eocene, and the change from discoidal Archaias to fusiform Fusarchaias in the Oligocene.

This progressive evolution of fusiform planispiral shells has been repeated so often that it is reasonable to believe that the elongate growth form has some advantage.

Several functional explanations for fusiform shape have been put forward. Hottinger (1978) suggested that it represents a device to shorten the line of communication between the first and last shell compartments by means of a polar passage way connecting the polar apertures of each chamber. This "runs as a high-spired, very narrow spiral around the polar columella, and is not much longer than the axial length of the shell. In Loftusia persica, the distance from the first to last chamber through the polar foramina is estimated to be only one tenth of that through the apertures located at the equator of the shell" (ibid., p. 221). This interpretation is supported by the fact that the polar face is enlarged and the polar apertures are multiplied or supplemented by additional fabulariid canals in the basal layer of fusiform alveolinids. This explanation does not agree, however, with the evidence for a progressive elongation of the growth axis, as outlined above, since this will tend to increase the polar line of communication. Hottinger $(1978$, p. 257) mentions that this elongation may have a supplementary function related to motility but concludes that the functional meaning of elongation is not understood.

The author has since briefly suggested that axial elongation represents a device to shorten lines of communication along the main spiral path linking each chamber (Brasier, 1982b, p. 24). This hypothesis is discussed further with the aid of the models described in the next section.

\section{EVOLUTIONARY MODELS}

The model represented in Fig. 1a is of a planispiral involute test with a wholly spheroidal section in the axial and equatorial plane. The number of chambers ( 92 plus megalospheric proloculus) and whorls (about 5.6, with 16 roughly equitant chambers per whorl) is arbitrary. Multiple apertures are arranged along the base of the apertural face from pole to pole. Thus the equatorial section shows a spiral foraminal pathway linking basal foramina and the model resembles Loftusia and Fusarchaias more closely than it does the Fusulinidae (with basal foramina but without external apertures) or the Alveolinidae (with areal aperture sand spiral foraminal pathways that are often nearer the outer margin of the chamber). The transformations discussed below, however, are of relevance to all these groups.

In the 'lineage' modelled from Figs. 1a to 1d, the test shape changes from spherical to cylindrical but the total volume of the test remains unchanged from one model to the next, as do the number of chambers per whorl and the chamber shape seen in the equatorial section. The extension of the involute chambers along the growth axis results in a reduction in the equatorial circumference and an increase in the surface area to volume ratio as well as (in this model) a reduction in the number of whorls and chambers for a unit volume of test. This means that the length of the spiral foraminal pathway 
(from proloculus to aperture) is reduced at the equator by more than $50 \%$ between Figs. $1 \mathrm{a}$ and $1 \mathrm{~d}$. The same must be true for the spiral passages in the extended zone on either side of the equator.

The 'lineage' modelled in Figs. 1a and $1 \mathrm{e}$ to $1 \mathrm{~g}$, is similar to the first lineage but the equatorial cross section (including the number of chambers and whorls) remains constant while the extension of chambers along the growth axis increases the total volume. The tests have external proportions comparable with those in the first lineage and the trends are therefore similar. But the shortening of the spiral MinLOC (for a unit volume) is not as great, since the number of whorls is not reduced.

The second cytoplasmic route, formed by the linking of polar apertures, is here taken as the length of a straight line from proloculus to polar extremity, though in practice it must be longer since it will twist around the axis like a corkscrew. It is obvious from Fig. 1 that the length of this polar path increases (per unit volume) in the lineage from globular to elongate fusiform tests. As
Hottinger (1978) has indicated, however, this polar passage is shorter than the spiral passage in all the models shown; the test of Fig. 1g would have to be about five times as long before the spiral path was shorter than the polar one, but in Fig. 1d, an extension of about $10 \%$ would achieve the same result. The relative importance of spiral and polar passages will therefore depend on the fairly complex relationship between the ratio of axial length to equatorial width, the number of whorls, the number and spacing of the chambers and the placement of the apertures.

\section{DISCUSSION}

If the factors just referred to above are not greatly altered in the evolution of a lineage, elongation of a fusiform test can be seen to have at least three possible advantages: 1) a greater relative surface area; 2) an increase in the length of the apertural face and in the number of apertures; 3 ) a shorter line of communication (for a unit volume) along the spiral cytoplasmic passages.

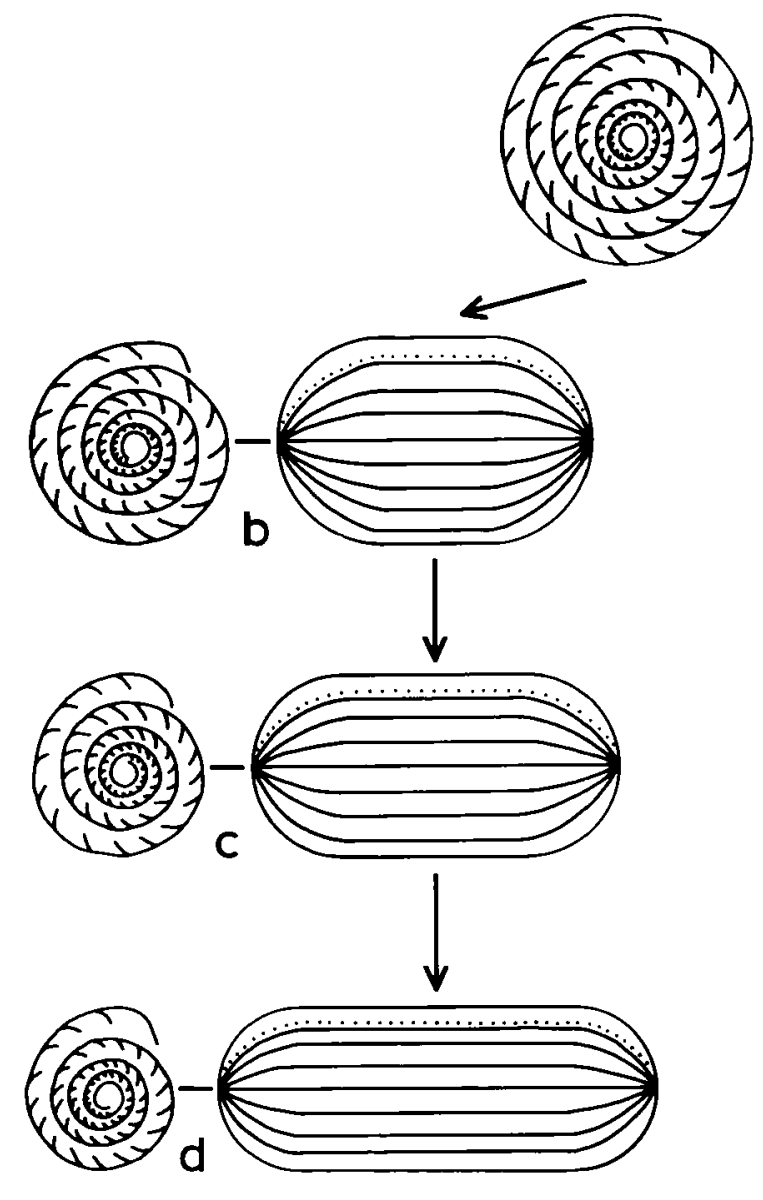

Equal volume; spiral MinLOC decreases; polar MinLOC increases. Surface area to volume increases.

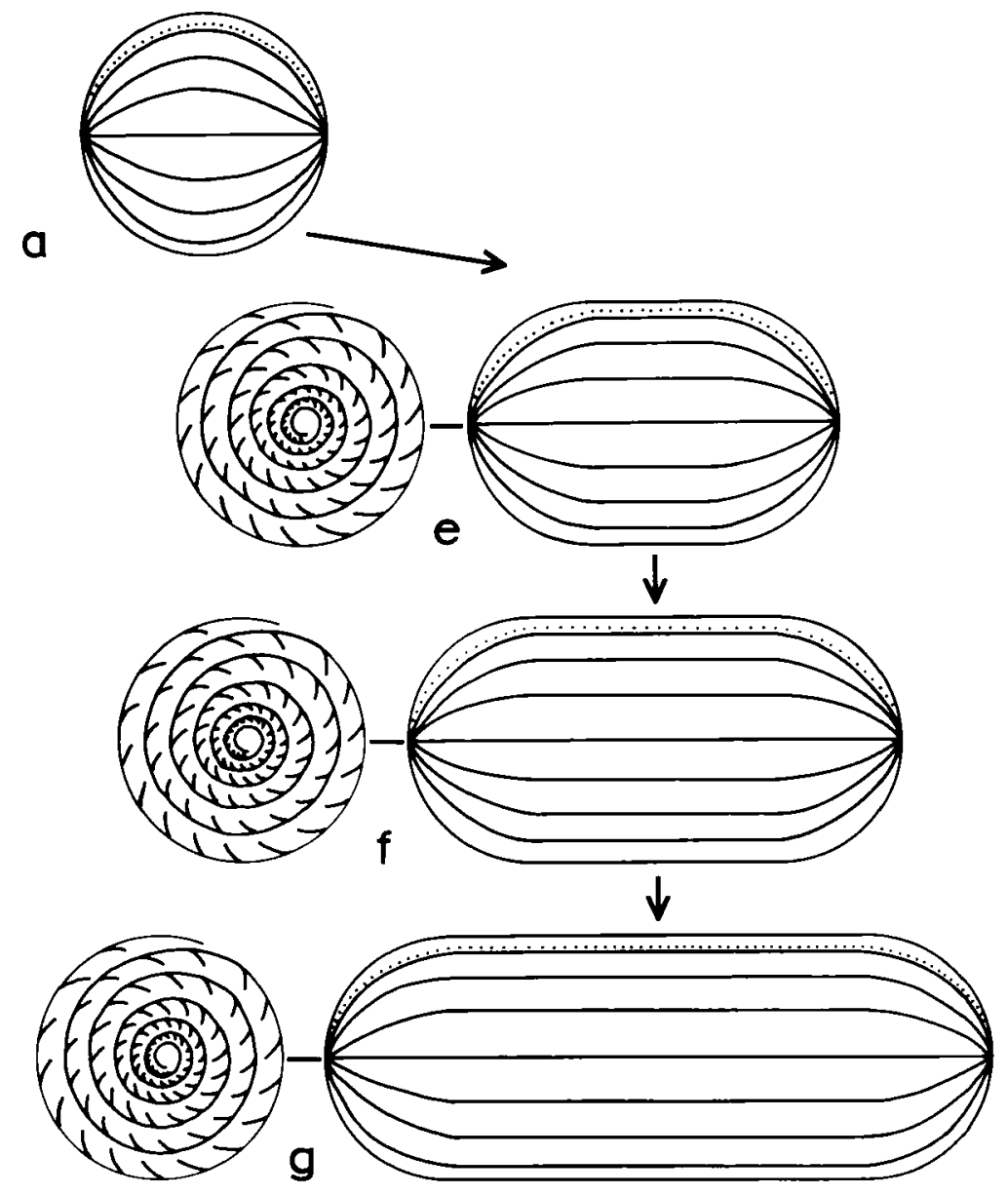

Equal spiral MinLOC; polar MinLOC increases; volume increases. Surface area to volume increases. 
The higher surface area may increase the proportion of chambers exposed to sunlight at any one time, thereby encouraging algal endosymbionts, if present. These have been reported in Alveolinella (Chaproniere, 1975) and are inferred in the fusulinids (Ross, 1974); appropriately, in both groups, the outer walls remain thin although the axial region may be thickened (Haynes, 1981, p. 56). An increase in the number of apertures may be conjectured to aid food collection and adherence because of the extension of a greater proportion of cytoplasm along the apertural face. But this would not necessarily be true of fusulinids since they lacked apertures. The shorter spiral passage would, for a given volume, improve the potential mobility of symbionts, organelles, vacuoles, nutrients and chemical substances through the test. One imagines this might improve the efficiency of cell physiology, leading to a potential for larger cells and larger tests.

But what is the significance of the polar line of communication, stressed by Hottinger (1978) as the basic reason for the fusiform planispiral shape? Several factors lead one to question its importance in that respect. Firstly, of course, is the trend for progressive elongation, just discussed, since this lengthens the polar pathways. The ideal trend for such a cytoplasmic path would be towards a discoidal shape with umbilical (i.e. polar) apertures and foramina (cf. Brasier, 1982a, fig. 1.10). Another contracdiction is that the majority of endoskeletal structures in fusiform planispiral foraminifera are arranged in the spiral direction (e.g. the chamberlets of the Alveolinidae and the tunnels, chomata and septal folds of Fusulinidae). The axial region may even be filled by secondary calcite deposits or flosculin, which tends to be thicker at the polar ends of the test making the polar path more difficult or more remote.

An interesting alternative to elongate fusiform growth is found in Multispirina, a late Cretaceous alveolinid. The test shape is spherical but composed of several interleaved spires (Reichel, 1947, 1964). Such multiple spires may seem to be a means of accelerating growth in larger foraminifera (Hottinger, 1978. p. 213) but they are also a means of shortening the lines of communication, since each spire is only a fraction of the length of a single spired test with equal volume. These multiple spires also make a polar cytoplasmic pathway impossible unless there is a connection between separate whorls. In Multispirina numerous small apertures along the sutures may connect the whorls in an irregular manner, making for short radial lines of communication throughout the test (cf. Brasier, 1982a, fig. 1.13d).

Thus lines of communication will get shorter with a greater degree of axial elongation, when other factors are held constant as modelled here, but it may be that the other factors change in a contrary manner. Greater flosculinisation of the chambers or tighter coiling of the whorls, for example, would lengthen the spiral MinLOC.
Care must therefore be taken in the analysis of MinLOC in such lineages. Hydrodynamic stability and relative strength are other adaptive aspects that deserve investigation; one imagines that elongation will improve stability and reduce resistance to transverse forces, though retaining resistance to compressive forces. Modelling unfortunately comes up against problems of scale here and the answers may have to be sought in experimental sedimentology and rock mechanics.

\section{ACKNOWLEDGEMENTS}

Mr. T. Thanoon kindly loaned alveolinid material from Iraq and Mr. P. McSherry assisted with the drawings. 


\section{REFERENCES}

Bignot, G. \& Guernet, C. 1976. Sur la présence de la Borelis curdica (Reichel) dans le Miocène de l'ile de Kos (Grèce) Géologie Mediterranéene. Annls Univ. Provence, 3, 15-26.

Brasier, M.D., 1975a. Morphology and habitat of living benthonic foraminiferids from Caribbean Carbonate environments. Revta esp. Micropaleont., 7, 567-578.

Brasier, M. D., 1975b. The ecology and distribution of Recent Foraminifera from the reefs and shoals around Barbuda, West Indies. J. foramin. Res., 5, 193-210.

Brasier, M.D. 1975c. An outline history of seagrass communities. Palaeontology, London, 18, 681-702.

Brasier, M.D. 1982a. Architecture and evolution of the foraminiferid test - a theoretical approach. In Banner, F. T. \& Lord, A. R. (Eds.), Aspects of Micropalaeontology, 1-41. George Allen \& Unwin, London.

Brasier, M. D., 1982b. Foraminiferid Architectural History: A review using the MinLOC and PI Methods. J. micropaleontol., London, 1, 95-105.

Chaproniere, G. C. H. 1975. Palaeoecology of Oligo-Miocene larger Foraminiferida, Australia. Alcheringa, 1, 37-58.

Haynes, J. R. 1981. Foraminifera. Macmillan, London.

Hottinger, L. 1960. Recherches sur les alvéolines du Paléocène et de l'Eocène. Schweiz. palaeont. Abh. (Mém. Soc. Pal. Suisse), 75/76, 1-243.

Hottinger, L. 1963. Les alvéolines Paléogènes, exemple d'un genre polyphylétique. In Von Koenigswald, G. H. R. et al. (Eds.), Evolutionary trends in Foraminifera, 298-314. Lawrence, Kansas.

Hottinger, L. 1978. Comparative anatomy of elementary shell structures in selected larger foraminifera. In Hedley, R. H. \& Adams, C. G. (Eds.), Foraminifera, 3, 203-266. Academic Press, London.
Hottinger, L. 1982. Larger Foraminifera, Giant Cells with a Historical Background. Naturwissenschaften, 69, 361-371.

Reichel, M. 1947. Multispirina iranensis, n. gen., n. sp., foraminifère nouveau du Crétacé supérieur de l'Iran. Schweiz. palaeont. Gesell. Abh. (Mém. Soc. Pal. Suisse), 65, 1-13.

Reichel, M. 1964. Alveolinidae. In Moore, R. C. (Ed.), Treatise on Invertebrate Paleontology, Pt. C, Protista, 2, (1), C503-C510a. Univ. Kansas Press.

Ross, C. A. 1969. Palaeoecology of Triticites and Dunbarinella in Upper Pennsylvanian strata of Texas. J. Paleont., 43, 298-311.

Ross, C. A. 1974. Evolutionary and ecological significance of large calcareous Foraminiferida (Protozoa), Great Barrier Reef. Proc. Sec. Int. coral reef Symp., 1, 327-333.

Smout, A.H. 1963. The genus Pseudedomia and its phyletic relationships, with remarks on Orbitolites and other complex foraminifera. In von Koenigswald, G. R.H. et al., (Eds.), Evolutionary trends in Foraminifera, 224-281. Elsevier Publishing Co., Amsterdam.

Tappan. H. 1976. Systematics and the species concept in benthonic foraminiferal taxonomy. Spec. Publ. Marit. Sediments, 1A, 301-313.

Thompson, M.L. 1964. Fusulinacea. In Moore, R. C. (Ed.), Treatise on Invertebrate Paleontology, Pt. C Protista, 2, (1), C358-C436. Univ. Kansas Press. 